\title{
An Empirical Investigation into the Applicability of Fama-French Three Factor Model in Explaining Portfolio Returns: Evidence from Non-Financial Firms on the Ghana Stock Exchange
}

\author{
Prince Acheampong ${ }^{1} \&$ Sydney Kwesi Swanzy ${ }^{1}$ \\ ${ }^{1}$ Department of Accountancy, Koforidua Polytechnic, Koforidua, Ghana \\ Correspondence: Prince Acheampong, Department of Accountancy, Koforidua Polytechnic, P.O. Box KF981, \\ Koforidua, Ghana.
}

Received: October 6, 2015

Accepted: November 6, 2015

Online Published: December 21, 2015

doi:10.5430/ijfr.v7n1p75

URL: http://dx.doi.org/10.5430/ijfr.v7n1p75

\begin{abstract}
This paper investigates the applicability of the Fama-French Three Factor Model in explaining, portfolio returns on the Ghana Stock Exchange. Following the model and variables proposed originally by Fama and French (1992), two additional variables firm size and Book-to-Market (BTM) ratio are added in a six Size-BTM portfolios to the excess returns on the market portfolio. Data from the Ghana Stock Exchange database covering the period between 2002 and 2011 were used for the analysis. The results reveal that the portfolio returns on the Ghana stock exchange are better explained by the three factor model proposed by Fama and French (1992).
\end{abstract}

Keywords: book-to-market ratio, portfolio, beta, risk free rate, excess returns

\section{Introduction}

In finance, the golden rule of asset management is that investors are rewarded based on the amount of un-diversifiable risk they hold on each security they invest in. However, investors and academicians in the world of finance have not yet conclusively dealt with the fundamental questions of; what the precise relationship between expected return and risk is? How much risk should an investor tolerate in order to realize anticipated returns? Furthermore investors as well as academicians had had to grapple with the question as to what business related factors affect the expected returns on their investments and how can they be measured? The quest to answering these key questions lies in the bosom of Asset Pricing Theory. Asset pricing theories suggest that investors; both individuals and institutions are rational. This infers that investors tend to invest in securities or assets that yield returns which they perceive to be commensurate with the level of risk associated with that investment.

Asset pricing theory involves the use of mathematically based models to reflect the possible exact equations or set of equations that seeks to provide a relationship between expected rate of return and risk (Hirschey \& Nofsinger, 2008).

The Asset Pricing Model of Sharpe (1964), Lintner (1965), and Black (1972) (SLB) provided finance professionals and academics a means of showing the relationship between the average returns on a stock or investments and the risk associated with it. This resulted in the pricing model known as the Capital Asset Pricing Model which is almost referred to as the CAPM. CAPM is based on the central idea that the market portfolio of invested wealth is mean-variant efficient as proposed earlier by Markowitz (1959). Markowitz assumed that a risk averse investor, who considers expected return and variance of an investment in a single period, will choose a portfolio in an ideal capital market which maximizes his/her expected return. Given the central idea of mean-variance efficiency of the market, it supports that investors choose portfolios that: (1) minimize the variance of portfolio return, for a given expected return, and (2) maximize expected return, for a given variance. This model has been the central piece of modern financial economics. This however implied that: the expected returns on securities are a positive linear function of their Market beta (the slope in the regression of a security's return on the market's return). Whiles this uni-factor model offered powerful and intuitive predictions about expected returns and risk, its applicability has come under severe criticism. Despite early test by Black, Jensen, and Scholes (1972), Black (1972), Fama and MacBeth (1973), all supporting the uni-factor model, CAPM, the explanatory power of systematic risk $(\beta)$, was put under scrutiny and exposed not to be the only factor that adequately describes returns of securities. 
Fama and French (2004) puts it that, the CAPM's empirical problems may reflect theoretical failings, the result of many simplifying assumptions. They further argue the model's problems are as a result of its weaknesses in the theory or in its empirical implementations. Acheampong and Agalega (2013), tested the applicability of the uni-factor model (CAPM) on selected stocks on the Ghana Stock Exchange (GSE) and the results using linear regressions showed that the model could not predict stock returns on the (GSE). This goes on to imply that, the failure of the CAPM in empirical tests indicated that most of the models applications were invalid.

These contradictions and empirical test failures of the SLB model, which is a one factor model of asset pricing, provided researchers with reasons that expected returns on securities could not be affected by just one factor, ' $\beta$ ', but that other factors might play significant role in determining returns on securities. This resulted in a new way of looking at asset pricing and hence the multi-factor asset pricing model emerged as a more realistic model which is able to explain the returns of securities based on not just one factor but other important variables that affected securities' returns (Bodie, et al., 2010).

Fama and French (1996) proposed a three-factor model in the quest to describing the returns on securities. This model is known as the Fama-French Three-Factor Model which is also a multi-factor asset pricing model that relates the returns on the securities to three relevant risk factors which have a high overall explanatory power as compared to other uni-factor models. The Fama- French Three Factor (FFTF) model which was proposed to explain the failures of CAPM which were seen as Anomalies, have been widely tested in other markets to ascertain its validity. The FFTF model explains returns on securities based on market beta, size, and book-to-market (BTM) ratio. This is widely explained and tested in the papers presented by Fama and French (1992) and also, Fama and French (1996). Despite the criticisms received by their findings, and that most of the critics pointed out survivorship and data snooping bias; other researches have been done to disprove most of the critics. Others argue the findings were specific to US stock, and new data must be used to test the validity of the model in different economies. This indeed is the reason why this paper is being written to provide evidence from Ghana and to find out whether earlier evidence by Fama and French (1996) are consistent with the Ghana Stock Market.

The aim of this paper is therefore to look at whether the evidence supporting the validity of Fama- French Three-Factor model in explaining the returns on common stocks in previous studies conducted in developed capital markets applies to Ghana's capital market which is a developing one.

\section{Review of Empirical Literature}

Below is a discussion of key empirical findings associated with the subject matter of this paper.

\subsection{Multifactor Model: Fama-French Three Factor Model}

Fama and French (1992) proposed a form of multi-factor model based on three factors and has become a standard tool for empirical studies of asset returns. They added firm size and book-to-market (BTM) ratio to the market index to explain average returns. These additional factors were motivated by earlier observations that average stocks returns of smaller firms and stocks with high BTM were historically being higher than predicted by the Security Market Line (SML) of the CAPM. This however, suggested that size and BTM may be proxies for exposure to sources of systematic risk not captured by the CAPM beta. Fama and French (1996) point out that firms with high BTM are more likely to be in financial distress and that small stocks may be more sensitive to changes in business conditions.

While the high book-to-market group includes many firms in financial distress which depresses market value relative to book value; for the most part, this group includes relatively mature firms. The latter derives a larger share of their market value from assets already in place, rather than growth opportunities. This group is often called "value-stocks". In contrast, low BTM companies are viewed as "growth firms" whose market values derive from anticipated future cash flows, rather than from assets already in place. Considerable evidence suggests that value stocks trade at lower prices than growth stocks (or equivalently, have offered a higher expected rate of return): the differential is termed as the value premium.

Fama and French (1996) argued that many of the CAPM average return anomalies were actually related and can be captured in its Three-Factor model. The model state that, the expected return on a portfolio in excess of risk-free rate $\left[E\left(R_{i}\right)-R_{f}\right]$ can be explained by the sensitivity of its return to three factors:

I. The excess return on a broad market portfolio $\left(R_{m}-R_{f}\right)$.

II. The difference between the returns on a portfolio of small stocks and the return of a portfolio of large stocks (SMB, Small minus Big). 
III. The difference between the returns on a portfolio of high book-to-market (BTM) stocks and the return on a portfolio of low book-to-market (BTM) stocks (HML, high minus low).

The model as proposed by Fama and French specifically, the expected excess return on portfolio ' $i$ ' $i s$

$E\left(R_{i}\right)-R_{f}=b_{i}\left[E\left(R_{m}\right)-R_{f}\right]+s_{i} E(S M B)+h_{i} E(H M L)$

$E\left(R_{i}\right)=$ expected returns on asset $i$

$E\left(R_{m}\right)=$ expected return on the market

$R_{f} \quad=$ risk-free rate

$b_{i} \quad=$ factor loading for excess return on market

$s_{i} \quad=$ factor loading for size

$h_{i} \quad$ factor loading for BTM

\subsection{The Size Effect}

The question as to why smaller firms earn higher returns than traditional asset pricing models predict has become the subject of a heated debate. Some papers contend that the systematic risk of a stock is driven by multiple risk factors, and firm size is a proxy for the exposure to state variables that describe time-variation in the investment opportunity set. An alternative interpretation is that the size premium is a compensation for trading costs and/or liquidity risk. A third fundamental explanation is embedded in asset pricing models that relax the assumption that investors are fully rational. Fama and MacBeth (1973) regressions showed a negative and significant relation between returns and market value. The size effect was not linear and was most pronounced for the smallest firms in the sample. Banz (1981) wrote what may be the first empirical paper that presents evidence of a size effect in US stock returns. He analysed all common stocks listed on the NYSE between 1936 and 1975. Banz (1981) reported that stocks in the quintile portfolio with the smallest market capitalization (size) earn a risk-adjusted return that was $0.40 \%$ per month higher than the remaining firms. He conjectures that many investors do not want to hold small stocks because of insufficient information, leading to higher returns on these stocks. Reinganum (1981) analysed the size effect in a sample of 566 NYSE and Amex firms over the period 1963 to 1977 . He found that the smallest size decile outperforms the largest by $1.77 \%$ per month. Brown et al. (1983) re-examined the size effect using the Reinganum data and found that there was an approximately linear relation between the average daily return on 10 size-based portfolios and the logarithm of the average market capitalization. Keim (1983) reported a size premium of no less than $2.5 \%$ per month in a broader sample of NYSE and Amex firms over the period 1963 to 1979. Keim shows that small firms had higher betas than large firms, but the difference cannot fully explain the return differential.

Based on 20 size-sorted portfolios using a very large sample of firms, Lamoureux and Sanger (1989) found a size premium of $2.0 \%$ per month for NASDAQ stocks and of $1.7 \%$ for NYSE/Amex stocks over the period 1973 to 1985. They documented that small firms had a lower beta than large firms on NASDAQ.

Although various important contributions appeared in the decade after the original work by Banz (1981), research on the size effect only really took off after the appearance of Fama and French (1992). They examined the size and book-to-market anomalies uncovered by earlier studies and made the case that the empirical shortcomings of the Capital Asset Pricing Model (CAPM) of Sharpe (1964) and Lintner (1965) are simply too important to be ignored. Using a sample of NYSE, Amex, and NASDAQ stocks over the period 1963 to 1990, Fama and French showed that the smallest size decile outperforms the largest by $0.63 \%$ per month. When they subdivided each size decile into 10 beta-sorted portfolios, they found no relation between beta and returns. Fama-MacBeth regressions confirm that beta does not help to explain the cross-section of returns, but both size and book-to-market equity have significant explanatory power.

Despite the load of studies supporting the size effects on returns. Critiques argue that most of these studies are either statistical flukes or as a result of data selections, and method of forming the portfolio sizes. Black (1993) makes a more general point that if researchers use a market portfolio that differs from the true market portfolio, betas are estimated with error. It is likely that stocks that seem to have low betas will on average have higher betas when the true market portfolio is used. This invalidates the analysis of whether the higher return on small stocks constitutes a premium for extra market risk. Pettengill et al (1995) investigated a different, but related issue. They criticized the Fama and French (1992) methodology for not taking into account that the predictions of the CAPM are based on expected returns and thus imposing the restriction that the beta-return relation was the same in up and down markets. When relaxing this restriction, Pettengill et al (1995) found a significantly positive beta in up markets and a significantly negative beta in down markets. Berk (2000) also criticized the approach of sorting stocks into size portfolios first and then testing the 
explanatory power of a certain asset pricing model within each size decile. He shows that this technique is biased toward rejecting whatever asset pricing model is examined in the second sorting step. The intuition is that in the first step, by picking a variable that is empirically known to have a relation to stock returns, the return variation across groups is relatively large. Hence, the variation within groups is small and the statistical power to reject the null of a flat beta-return relation is low. In a follow-up study, Pettengill et al (2002) showed that the cross-sectional return premium associated with firm size was also asymmetric: the size effect is much more pronounced in down markets. They argue that the common assumption that betas are the same in up and down markets leads to an underestimation of the size effect. Ferguson and Shockley (2003) demonstrated that if the market proxy in empirical tests of the CAPM was equity only, characteristics correlated with a firm's relative leverage and relative distress (such as firm size) will appear to explain returns. Clearly research is not conclusive on the exact relationship between the firm size and expected returns. Furthermore, none of such study has been carried out in the context of the Ghana stock exchange. It is therefore essential that the size effect is analysed in a portfolio context using data from Ghana.

\subsection{Book-to-Market (BTM) Ratio Effect}

The book value of a firm is the difference between total assets (resources expected to result in inflows of economic benefits) and total liabilities (obligations expected to result in outflows of economic benefits), or a measure of net expected inflows of economic benefits, or earnings. However, there is inherent uncertainty surrounding those earnings. The book-to-market (BTM) ratio, is the ratio of book value of equity (total assets minus total liabilities) as per the balance sheets to market value of equity (stock price times the number of shares outstanding). The evidence that size and book-to-market-equity proxy for sensitivity to risk factors in returns is consistent with a rational-pricing story for the role of size and BTM in average returns. But return tests cannot tell a complete economic story. Size and BTM remain arbitrary indicator variables that, for unexplained economic reasons, are related to risk factors in returns.

Economists and financial practitioners have sought to identify variables that predict stock returns. The use of the book-to-market ratio is motivated by the findings of Fama and French (1992), who showed that the book-to-market ratio of individual stocks had the ability to explain cross-sectional variation in stock returns. An independent paper by Kothari and Shanken (1997) uses a Bayesian framework to document that the book-to-market ratio of the Dow Jones Industrial Index (DJIA) predicts market returns over the period 1926 to1991. They provide evidence that the book-to-market ratio sometimes predicts negative expected returns, although this finding is not robust to the latter half of their sample. Literature documenting the explanatory power of the BTM ratio over stock returns is not scarce. Most recent studies on this variable include those of Fama and French (2000), Ho et al (2000), Griffin and Lemmon (2002), Drew et al (2003) to name but a few. These studies were conducted across several markets including those in the U.S., U.K., Hong Kong, Korea, Malaysia, Italy and the Philippines. Akgun and Gibson (2001), on the other hand, suggest that BTM (as well as size) may subsume useful information regarding both the probability of bankruptcy and recovery rates, as well as distress risk. Vassalou and Xing (2004) posit that the BTM effect is largely a default effect, but exists only in segments of the market with high default risk.

Based on the above evidence some of which support the Fama and French three-factor model whiles others critiqued the models estimations and applicability in assessing the returns of stocks on the developed markets; the purpose of this paper is to extend the discussion to include a developing market; the Ghana Stock Exchange.

\section{Empirical Methodology}

The empirical procedures adopted for this paper are as discussed below.

\subsection{Sources and Type of Data}

The data for this paper include end of month closing stock prices of non- financial firms listed on the Ghana Stock Exchange (GSE) from January 2002 to December 2011. The study period was selected because of the improvement of the workings of the exchange as well as increased number of companies listing on the exchange, during this time period. The data period also reflected the time when the market was seen to be growing and there was a good feeling about the Ghanaian capital market and saw a rise in the market capitalisation of the GSE.

This comprises of both de-listed and listed firms during the study period. The data provides the values for all surviving firms during the period and only firms which were delisted during the period of study have missing values corresponding to the time after delisting. This data selection was done to dispel data snooping bias argument. This paper uses only non-financial firms, since financial firms normally have high leverage and the implication of high leverage to financial firms are different to non-financial firms. The accounting data used in computing the Book-to-Market (BTM) and size were obtained from the GSE facts books, as well reported annual financial statements of the firms involved. Thus, only secondary data were used in this paper. 


\subsection{Empirical Model Specification}

Following Fama and French (1993) three factor model, the model adopted for this paper is specified as follows:

$E\left(R_{i}\right)-R_{f}=b_{i}\left[E\left(R_{m}\right)-R_{f}\right]+s_{i} E(S M B)+h_{i} E(H M L)$

Where,

$E\left(R_{i}\right)=$ expected returns on asset/portfolio $i$

$E\left(R_{m}\right)=$ expected return on market

$R_{f} \quad=$ risk-free rat

$b_{i} \quad=$ factor loading for excess return on market

$s_{i} \quad=$ factor loading for siz

$h_{i} \quad$ factor loading for BTM

\subsection{Size-BTM Portfolios Formation Process}

Since the GSE is a fairly small market a six (6) Size-BTM portfolios is formed. Firstly, stocks are sorted from the smallest to the biggest in terms of market capitalization or value. The stocks after being sorted from the smallest to the biggest were then divided into two groups by using the mid-point (median) of the market value of the sample stocks at the end of each year. Portfolios whose market value were lower than the median were designated as small size(S) and those whose market value were bigger than the median were assigned as big size (B).

The stocks after being sorted into two groups on the basis of size, were then sorted into three BTM portions independently by their BTM ratios again. This sorting into BTM portioning is done for each year of the study period. The partitions were designated as High (H), Medium (M), and Low (L). The breakpoints or levels for the partitioning was the top $30 \%, 40 \%$ midsection, and bottom $30 \%$ of the BTM figures that were computed. The high BTM ratios portfolios contained the top 30\% BTM ratio of stocks. The medium BTM ratios portfolios were those that were found in $40 \%$ section of the BTM ratios of the stocks, and the bottom 30\% BTM ratios of stocks were for the low BTM portfolios. The paper looked at 120 months, which is from January 2002 to December 2011, which is a ten year period. The paper uses the six portfolios due to the small population of listed companies on the GSE. Its worthy of note that the GSE is a very young market compared to the US stock market which was used in the study by Fama and French (1993). Table 1 presents the formation of the size-BTM portfolios.

Table 1. The formation of the size-BTM portfolios

\begin{tabular}{|c|c|c|c|c|}
\hline & & \multicolumn{3}{|l|}{ BTM } \\
\hline & & $\mathrm{H}$ & $\mathrm{M}$ & $\mathrm{L}$ \\
\hline \multirow[t]{2}{*}{ SIZE } & $S$ & $\mathrm{SH}$ & SM & SL \\
\hline & B & $\mathrm{BH}$ & $\mathrm{BM}$ & BL \\
\hline
\end{tabular}

\subsection{Estimation of Model Parameters}

\subsubsection{Portfolio Returns (Dependent Variable)}

The portfolios returns were computed as equal weighted returns of the stocks in each of the six portfolios. The computing of the returns were done for all the six portfolios. This produced a monthly returns over the period from 2002 to 2011 for each of the six (6) Size-BTM portfolios. The study considered 120 monthly returns during this period. The monthly returns $\left(R_{i, t}\right)$ was derived by using the formula:

$$
\mathrm{R}_{\mathrm{i}, \mathrm{t}}=\frac{\mathrm{P} i, t-\mathrm{P} i, t-1}{\mathrm{P} i, t-1}
$$

Where,

$R_{i, t}=$ monthly returns of stock $i$ at end of month $t$ 
$P_{i},=$ closing stock price at the end of month

$P_{i},-1=$ closing stock price at the end of previous month $t-1$

The portfolio returns is derived by finding the equal weighted average of all the monthly returns of the individual stocks in the portfolio. It's derived by the formula below as:

Where,

$$
P R i, t=\frac{\sum_{i=1}^{n} R_{i, j}}{n_{p}}
$$

$P R_{i, t}=$ monthly returns of portfolio at end of month

$R_{i, t}=$ monthly returns of stock $i$ in the portfolio at end of month $t$

$n_{p}=$ number of stocks in the portfolio at end of month $t$

\subsubsection{Market Excess Returns (Independent Variable)}

The monthly market return was calculated by computing market weighted average returns of all the stocks in the six portfolios for each month including firms which were exclude from portfolio sorting due to them having negative BTM, hence the returns of all the non-financial firms both listed and delisted during the study period. The formula for the monthly market returns is as follows:

Where,

$$
R_{m t}=\frac{\sum_{i=1}^{n}\left[\left(X_{i,} P_{i}\right) R_{i, t}\right]}{\sum_{i=1}^{n}\left(X_{i} P_{i}\right)}
$$

$R_{m, t}=$ monthly market return for the month $t$

$X i=$ the outstanding number of shares of stock ' $i$ ' at the end of each year or period

$P i \quad=$ the price of stock ' $i$ ' at the end of the year or period

$R_{i,}=$ monthly returns of all stocks $i$ of non-financial firms during study period both listed and de-listed

The market premium or excess returns were calculated from the market monthly return minus risk-free rate. Due to the unavailability of 1-month Treasury bill rate in Ghana, the 91-days Treasury bill rate was used as a proxy for the risk free rate.

\subsubsection{Firm Size (Independent Variable)}

The firm size factor (SMB), which is the difference between the monthly simple average returns of small-size stock portfolios (SH, SM, and SL) and that of monthly average returns of big-size stock portfolios (BH, BM, and BL).

The formula is derived as follows:

$$
S M B=\frac{(S H+S M+S L)}{3}-\frac{(B H+B M+B L)}{3}
$$

\subsubsection{Book-to-Market Ratio (BTM) (Independent Variable)}

The third independent variable is the BTM ratio factor (HML), which is the difference between the portfolios simple average returns on the two high-BTM ratio portfolios ( $\mathrm{SH}$ and $\mathrm{BH}$ ) and the portfolios simple average returns on the two low BTM ratio stock portfolios (SL and BL). The formular is as below:

$$
H M L=\frac{(S H+B H}{2}-\frac{(S L+B L)}{2}
$$

These are the independent variables which were used for the Fama and French Model, excess market returns, firm size (SMB), and BTM ratio (HML).

\subsection{Data Evaluation and Model Selection}

Since time series data, was employed it seemed prudent to run diagnostic test on the data before running any regression on the data. This is normally done to ensure that certain underlying assumptions are met. To do so, a test on the data must be done by testing of the residuals for the presence of serial correlation and heteroskedasticity as well as testing for the unit root to determine the stationarity of the data. However if these test were done, and the test found the data to be either heteroskedastic or non-stationary. It required the data to be transformed. However many researchers argue 
that these data transformation processes may lead to the introduction of biases in the estimation of the coefficients. To deal with this problem of heteroskedasticity and non-stationarity of the data, therefore, the regression is run by a robust regression methods, which according to Stock and Watson (2011) takes care of these data challenges.

\section{Presentation of Results, Analysis and Discussion}

Presented and discussed below are the empirical results from the model.

4.1 Descriptive Statistics for 6 Stock Portfolios Formed on Size and Book-to- market Equity

Table 2. Descriptive statistics for 6 stock portfolios formed on size and book-to- market equity: 2002-2011

\begin{tabular}{|c|c|c|c|c|c|c|c|}
\hline stats & $\mathrm{N}$ & Mean (\%) & SD & p50 (\%) & $\operatorname{Min}(\%)$ & $\operatorname{Max}(\%)$ & t-test \\
\hline rmrf & 120 & -16.1453 & 7.695552 & -15.6854 & -32.6274 & 18.80445 & $-22.9825 * * *$ \\
\hline $\mathrm{smb}$ & 120 & -0.5237 & 4.651688 & -0.42329 & -16.5066 & 14.44306 & -1.2333 \\
\hline $\mathrm{hml}$ & 120 & 1.385675 & 4.930849 & 0.894047 & -11.632 & 16.04679 & $3.0784 * * *$ \\
\hline sh & 120 & 2.061753 & 6.040249 & 0.292499 & -11.4003 & 29.698 & $3.7391 * * *$ \\
\hline $\mathrm{sm}$ & 120 & 1.068945 & 6.605335 & 0 & -25 & 33.33333 & $1.7728 * *$ \\
\hline sl & 120 & -0.15974 & 4.313697 & 0 & -23.0769 & 28.2441 & -0.4056 \\
\hline $\mathrm{bh}$ & 120 & 1.768252 & 6.668835 & 0.101747 & -21.5884 & 33.9779 & $2.9046 * * *$ \\
\hline $\mathrm{bm}$ & 120 & 1.555405 & 5.673051 & 0.225474 & -12.0077 & 26.92308 & $3.0034 * * *$ \\
\hline bl & 120 & 1.218391 & 6.041194 & 0.292385 & -12.5114 & 28.24357 & $2.2093 * *$ \\
\hline shrf & 120 & -15.4386 & 8.484436 & -14.3952 & -39.2464 & 6.422535 & $-19.9331 * * *$ \\
\hline smrf & 120 & -16.4314 & 9.078554 & -14.0329 & -37.15 & 23.96333 & $-19.8266^{* * *}$ \\
\hline slrf & 120 & -17.6601 & 8.019182 & -17.0206 & -38.3741 & 11.3441 & $-24.1242 * * *$ \\
\hline bhrf & 120 & -15.7321 & 9.522464 & -14.7025 & -47.6884 & 21.4779 & $-18.0979 * * *$ \\
\hline bmrf & 120 & -15.9449 & 8.270515 & -14.3971 & -31.4174 & 10.62308 & $-21.1194 * * *$ \\
\hline blrf & 120 & -16.2819 & 9.105905 & -17.1 & -34.3547 & 10.44357 & $-19.5873 * * *$ \\
\hline
\end{tabular}

$\mathrm{p}<0.1^{*} \mathrm{p}<0.05 * * \mathrm{p}<0.001 * * *$

legend (sh-return on small size but high BTM portfolio, sm-return on small size but medium BTM portfolio, sl-return on small size but low BTM portfolio; bh-return on big size but high BTM portfolio, bm-return on big size but medium BTM, bl-return on big size but low BTM portfolio, shrf, smrf, slrf, bhrf, bmrf, blrf, their respective excess returns, thus shrf is sh minus risk-free; rmrf-market return minus risk-free.

Source: (Authors own construct, survey data, 2015)

The results in Table 2 show that monthly average mean returns for small firm population is $0.9903 \%$ and for big firms is $1.5140 \%$, the $t$-statistic for the standard deviations for the means of the six size-BTM portfolios shows significant differences between the standard deviations, although only portfolio SL showed no significance at neither $10 \%, 5 \%$, nor $0.1 \%$ significance levels. The average standard deviations for the small firms is 5.6530 and the big firms is 6.1277 . This implies that the big firm portfolios returns are more volatile than the small firm portfolios, as a result the big firm portfolios have a higher risk than the small firm portfolios, and also the large firm portfolios more profitable than the small firm portfolios. For the BTM, the high BTM portfolios mean returns is $1.9150 \%$ and the low BTM portfolios is 
$0.5293 \%$, this means that high BTM portfolios mean returns are higher than low BTM portfolios. The average standard deviations for the high BTM portfolios is 6.3545 and that of low BTM is 5.1774. This implies that the high BTM portfolios are more risky than the low BTM portfolios.

The size factor, SMB, is negative and the mean is $-0.5237 \%$ but is not significant at neither $10 \%, 5 \%$, nor $0.1 \%$ significance levels. This implies the size effect is weak considering the Ghana Stock market. The average return of $-0.5237 \%$ per month is different from that recorded by Fama and French (1993) which was $0.27 \%$.

The BTM factor, HML, is positive and the mean is $1.3857 \%$ per month and it is significant at $0.1 \%$ significance level. This implies that there is a strong BTM effect on the returns on the Ghana Stock Exchange. The findings of Fama and French (1993) however was $0.4 \%$ per month.

\subsection{Correlation Matrix among the Independent Variable and Dependent Variable}

The level of interaction amongst the independent and dependent variables, is revealed by the correlation matrix. This provides the ability to check the extent of multicollinearity among the variables. Table 3 presents the correlation matrix of the independent and dependent variables.

Table 3. Correlation matrix of independent and dependent variables

\begin{tabular}{|c|c|c|c|c|c|c|c|c|c|}
\hline & smb & $\mathrm{hml}$ & rmrf & shrf & smrf & slrf & bhrf & bmrf & blrf \\
\hline $\mathrm{smb}$ & 1 & & & & & & & & \\
\hline hml & $.089 *$ & 1 & & & & & & & \\
\hline rmrf & $-.180^{* *}$ & $-.062 *$ & 1 & & & & & & \\
\hline shrf & $.161 *$ & $.245^{* * * *}$ & $.610^{* * *}$ & 1 & & & & & \\
\hline smrf & $.308^{* * *}$ & $.088^{*}$ & $.580^{* * *}$ & $.531^{* * *}$ & 1 & & & & \\
\hline slrf & $.070 *$ & $-.266^{* * *}$ & $.698^{* * *}$ & $.636^{* * * *}$ & $.594^{* * *}$ & 1 & & & \\
\hline bhrf & $-.379^{* * *}$ & $.297 * * *$ & $.654^{* * *}$ & $.515^{* * *}$ & $.542^{* * *}$ & $.648^{* * *}$ & 1 & & \\
\hline bmrf & $-.234^{* *}$ & $-.063 *$ & $.714^{* * *}$ & $.652^{* * *}$ & $.586^{* * *}$ & $.663^{* * *}$ & $.543^{* * *}$ & 1 & \\
\hline blrf & $-.404^{* * *}$ & $-.309^{* * *}$ & $.705^{* * *}$ & $.645^{* * * *}$ & $.444 * * *$ & $.678^{* * *}$ & $.633^{* * *}$ & $.658^{* * *}$ & 1 \\
\hline
\end{tabular}

*. Correlation is significant at the 0.1 level (2-tailed). **. Correlation is significant at the 0.05 level (2-tailed).

***. Correlation is significant at the 0.01 level (2-tailed).

Source: (Authors own construct, Survey data, 2015)

From the Table 3, it can be inferred that there is no multicollinearity among the independent variables namely, firm size (SMB), BTM factor (HML), and excess market return (rmrf). The results indicate that the correlation coefficients amongst them is less than 0.5. A negative correlation is recorded between smb and rmrf and is significant at $5 \%$ significance level. This suggests an inverse relationship between size and excess market return. The correlation of hml and rmrf is negative and significant at $10 \%$ significance level. Furthermore, there exist a positive correlation between $\mathrm{hml}$ and smb which is significant at $10 \%$ significance level. Also, there exist a strong positive correlation between rmrf and all six dependent variables (shrf, smrf, slrf, bhrf, bmrf, blrf) and are all significant at $1 \%$ significance level. This demonstrations the relationship between excess portfolio returns and market beta. The results from Table 3 also shows a weak correlation of smb and excess portfolio returns which are statistically significant. However, the correlation of smb and small firm portfolio excess' are positive but negative to big firm portfolio return excesses. This means that the smaller size portfolios have a positive effect to firm size, whilst bigger size portfolios have a negative effect to firm size. Table 3 also reveals a positive correlation between $\mathrm{hml}$ and high BTM portfolios excess returns (shrf and bhrf), whilst a negative correlation between $\mathrm{hml}$ and low BTM portfolio excess return (slrf and blrf) all being statistically significant. There exist also a positive correlation among all the dependent variables and are statistically significant. 


\subsection{Regression Analysis of Fama and French Three Factor Model}

Table 4 presents the regression results of the excess portfolios return for the six size-BTM portfolios on market factor, size factor (SMB), and BTM factor (HML).

Table 4. Regression results of the Fama and French Three Factor Model

\begin{tabular}{llllllll}
\hline Variable & $\alpha$ & $\beta$ & $S_{i}$ & $h_{i}$ & $\mathrm{~N}$ & R- & ADJ. \\
& & & & & $\mathrm{R}$ \\
& & & & & & SQUARED & SQUARED \\
\hline SHRF & -3.8448657 & $.74171808^{* * *}$ & $.47159831^{* *}$ & $.45358857^{* * *}$ & 120 & 0.516624 & 0.504123 \\
\hline SMRF & -3.6349811 & $.78047376^{* * *}$ & $.81832382^{* * *}$ & 0.16824579 & 120 & 0.521382 & 0.509004 \\
\hline SLRF & -4.7587908 & $.7529803^{* * *}$ & $.38201139^{* *}$ & $-.3926763^{* *}$ & 120 & 0.583878 & 0.573116 \\
\hline BHRF & -4.5871895 & $.77023008^{* * *}$ & $-.61242911^{* * *}$ & $.70000831^{* * *}$ & 120 & 0.628253 & 0.618638 \\
\hline BMRF & -3.9781833 & $.74597421^{* * *}$ & -0.19279519 & -0.01712335 & 120 & 0.521817 & 0.50945 \\
\hline BLRF & -3.6732645 & $.75896786^{* * *}$ & $-.52284217^{* * *}$ & $-.45372686^{* * *}$ & 120 & 0.635882 & 0.626465 \\
\hline
\end{tabular}

Source: (Authors own construct, Survey data, 2015).

$* \mathrm{p}<0.05 ; * * \mathrm{p}<0.01 ; * * * \mathrm{p}<0.001$

The market factor slopes in Table 4 are all positive and statistically significant at $0.1 \%$ significance level. The average slope for the market is 0.758391 and this suggests that market factor is related to portfolio excess return, which assumes an important role in explaining portfolio excess returns.

The six Size-BTM portfolios' coefficients are highly significant for 5 out of 6 portfolios. SM, BH, and BL portfolios are significant at $0.1 \%$ significance level, $\mathrm{SH}$ and SL are significant $5 \%$ significance level, however BM is insignificant neither at $5 \%, 1 \%$, nor $0.1 \%$. The slopes of all the small firm portfolios are positive whiles all the big firm portfolios' coefficients are negative. This finding corroborates Fama and French (1993) who pointed to the fact that small firm portfolios' returns were higher than those of big firm portfolios.

The slopes of the BTM factor are all significant except SM and BM. The portfolio SH, BH, and BL are significant at $0.1 \%$ significance level and portfolio SL is significant at $1 \%$ significance level. The portfolios SM and BM are insignificant neither at $5 \%, 1 \%$, nor $0.1 \%$ significance level. It can be observed that the slopes of the high BTM portfolios are higher than low BTM portfolios. Within each of the two size portfolios the slopes of BTM factor increased from low BTM portfolios to high BTM portfolios. All this provides evidence of the BTM effect on the Ghana stock Market. The results from our study corroborate with earlier researchers, including, Fama and French (1993) who posit that firm size and Book-to-Market ratio help in predicting portfolio excess returns.

The average adjusted $\mathrm{R}^{2}$ value of the six size-BTM portfolios is 0.556799 . The $\mathrm{BL}$ portfolio gave the highest $\mathrm{R}^{2}$ value of 0.626465 , whilst the lowest $\mathrm{R}^{2}$ value is SH portfolio. This implies returns of big firms with low BTM are better explained by the FFTFM compared to small firms with high BTM.

The results from the regression demonstrated that the Fama and French Model can be used on the Ghana's Stock Market to predict the returns of stocks listed. This is seen in the fact the additional factors of firm size(SMB) and BTM (HML) which are added to the market factor provided the Model enough explanatory factors to describe the returns. This is buttressed with the fact that the intercept of all size portfolios were statistically insignificant. Furthermore the regression coefficients of firm size and BTM provides evidence that there exist in the Ghana Stock Market the effects of size and BTM. The betas for all the six size-BTM were positive and significant and goes to show that beta cannot be underestimated when dealing with selecting explanatory factors for returns on the Ghana Market. This is however opposite to the findings of Fama and French (1992), who stipulated that beta is flat in explaining returns. This research showed also that small firm portfolios tend to have higher returns than large firm portfolios, this was evident in the fact that the small firm portfolios had positive slopes and big firm portfolios had negative slopes. This results were consistent with the Fama and French (1993). This paper has also shown that high BTM portfolios tend to have higher 
returns than low BTM portfolios, this is revealed by the positive slopes for high BTM portfolios and the negative Slopes for Low BTM portfolios. The major inference from the regression was the fact that the $\mathrm{R}^{2}$ value of the Fama and French was higher. This made the Fama and French Model a better model in predicting asset returns on the Ghana Stock Market.

\section{Conclusion and Policy Implications}

This paper affirms the fact that beta and market factor cannot be the only determinants of variations in asset returns. The study has proven that using a multifactor model like the Fama and French Three Factor Model, is a better asset pricing model which provides three important explanatory factors; market factor, firm size, and BTM factor, in explaining the returns of stocks on the Ghana Stock Market. The study further proves the influence of the size effect, initially proposed by Banz (1981), as one of the factors that affects returns on the Ghana Stock Market. The BTM effect is also prominent on stocks on the Ghana Stock Market and is to be considered when predicting future returns.

What can be realized from this paper is that portfolio managers working with stocks listed on the Ghana Stock Exchange must decide how much of each of the three risk factors they are willing to cushion when they are forming their portfolios. They must manage the risk-benefit trade-offs between the three factors to suit their threshold for the various risk factors. What this means is, they must be able to manage their risk exposures by identifying the true sources of risk. Doing so can maximise their returns at a lower cost. What is also clear from this paper is that the increased expected returns do not depend on any extraordinary performance by an active portfolio manager as shown by the statistically insignificant nature of the alpha values or regression intercepts of the Fama and French Three Factor Model. From this study it is clear that the Fama and French Three Factor Model is better in explaining the returns on the Ghana Stock Market. This means that, portfolio managers who want to earn higher returns can do so by knowing which stocks will best increase their returns based on the three factors of the Fama and French Model.

Furthermore due to the effectiveness of the Fama and French Model in explaining excess portfolio returns it is prudent to recommend that financial analysts as well as academicians devotes more attention to the practicability of this Model and be used more in the world of business to evaluate asset returns.

\section{References}

Acheampong, P., \& Agalega, E. (2013). Does the Capital Assets Pricing Model (CAPM) Predict Stock Market Returns in Ghana? Evidence from Selected Stocks on the Ghana Stock Exchange. Research Journal of Finance and Accounting,4(9).

Akgun, A., \& Gibson, R. (2001). Recovery Risk in Stocks Returns. The Journal of Portfolio Management, 27(2), 22-31. http://dx.doi.org/10.3905/jpm.2001.319789

Banz, R. W. (1981). The Relationship between Return and Market Value of Common Stocks. Journal of Financial Economics, 9(1), 3-18. http://dx.doi.org/10.1016/0304-405X(81)90018-0

Berk, J. B. (2000). Sorting Out Sorts. Journal of Finance, 55(1), 407-427. http://dx.doi.org/10.1111/0022-1082.00210

Black, F. (1972). Capital Market Equilibrium with Restricted Borrowing. Journal of business, 45(3), 444-455. http://dx.doi.org/10.1086/295472

Black, F. (1993). Beta and Return. The Journal of Portfolio Management, 20(1), 8-18. http://dx.doi.org/10.3905/jpm.1993.409462

Black, F., Jensen, M. C., \& Scholes, M. S. (1972). The Capital Asset Pricing Model: some empirical test. In Michael C. Jensen (Ed.), Studies in The Theory of Capital Market. New York: Praeger.

Bodie, Z., Kane, A., \& Marcus, A. J. (2010). Essentials of Investment (8th ed.). New York: McGraw-Hill/Irwin.

Brown, P., Kleidon, A. W., \& Marsh, T. A. (1983). New Evidence on the Nature of Size-Related Anomalies in Stock Prices. Journal of Financial Economics, 12(1), 33-56. http://dx.doi.org/10.1016/0304-405X(83)90026-0

Drew, M. E., Naughton, T., \& Veeraraghavan, M. (2003). Firm Size, Book-to-Market Equity and Security Returns: Evidence from the Shanghai Stock Exchange. Australian Journal of Management, 28(2), 119-139. http://dx.doi.org/10.1177/031289620302800201

Fama, E. F., \& French, K. R. (1992). The Cross-section of Expected Stock Returns. The Journal of Finance, 47(2), 427-465. http://dx.doi.org/10.1111/j.1540-6261.1992.tb04398.x 
Fama, E. F., \& French, K. R. (1993). Common Risk Factors in the Return of Stocks and Bonds. Journal of Financial Economics, 33(1), 3-56. http://dx.doi.org/10.1016/0304-405X(93)90023-5

Fama, E. F., \& French, K. R. (1996). Multifactor Explanations of Asset Pricing Anomalies. Journal of Finance, 51(1), 55-84. http://dx.doi.org/10.1111/j.1540-6261.1996.tb05202.x

Fama, E. F., \& French, K. R. (2004). The Capital Asset Pricing Model: Theory and Evidence. Journal of Economic Perspectives, 18(3), 25-46. http://dx.doi.org/10.1257/0895330042162430

Fama, E. F., \& MacBeth, J. D. (1973). Risk, Return, and Equilibrium: Empirical Tests. The Journal of Political Economy, 81(3), 607-636. http://dx.doi.org/10.1086/260061

Ferguson, M. F., \& Shockley, R. L. (2003). Equilibrium "Anomalies". Journal of Finance, 58(6), 2549-2580. http://dx.doi.org/10.1046/j.1540-6261.2003.00615.x

Griffin, J. M., \& Lemmon, M. L. (2002). Book-to-Market Equity, Distress Risk, and Stock Returns. The Journal of Finance, 47(5), 2317-2336. http://dx.doi.org/10.1111/1540-6261.00497

Hirschey, M., \& Nofsinger, J. (2008). Investments: Analysis and Behaviour (1st ed.). New York: McGraw-Hill/Irwin.

Ho, Y.-W., Strange, R., \& Piesse, J. (2000). CAPM Anomalies and the Pricing of Equity: Evidence from the Hong Kong Market. Applied Economics, 32(12), 1629-1636 http://dx.doi.org/10.1080/000368400419014

Keim, D. B. (1983). Size-Related Anomalies and Stock Return Seasonality: Further Empirical Evidence. Journal of Financial Economics, 12(1), 13-32. http://dx.doi.org/10.1016/0304-405X(83)90025-9

Kothari, S., \& Shanken, J. (1997). Book-to-Market, Dividend Yield, and Expected Market Returns: a Time-Series Analysis. Journal of Financial Economics, 44(2), 169-203. http://dx.doi.org/10.1016/S0304-405X(97)00002-0

Lamoureux, C. G., \& Sanger, G. C. (1989). Firm Size and Turn-of-the-Year Effects in the OTC/NASDAQ Market. Journal of Finance, 44(5), 1219-1245. http://dx.doi.org/10.1111/j.1540-6261.1989.tb02651.x

Lintner, J. (1965). The Valuation of Risk Assets and Selection of Risky Investments in Stock Portfolios and Capital Budgets. The Review of Economics and Statistics, 47(1), 13-37. http://dx.doi.org/10.2307/1924119

Markowitz, H. M. (1959). Portfolio Selection: Efficient Diversification of Investments. New York: John Wiley \& Sons, Inc.

Pettengill, G. N., Sundaram, S., \& Mathur, I. (1995). The Conditional Relation between Beta and Returns. The Journal of Financial and Quantitative Analysis, 30(1), 101-116. http://dx.doi.org/10.2307/2331255

Pettengill, G. N., Sundaram, S., \& Mathur, I. (2002). Payment for Risk: Constant Beta Vs. Dual-Beta Models. Financial Review, 37(2), 123-135. http://dx.doi.org/10.1111/1540-6288.00008.

Reinganum, M. R. (1981). Misspecification of Capital Asset Pricing: Empirical anomalies based on earnings' yields and market values. Journal of Financial Economics, 9(1), 19-46. http://dx.doi.org/10.1016/0304-405X(81)90019-2

Sharpe, W. F. (1964). Capital Asset Prices: A Theory of Market Equilibrium under Conditions of Risk. The Journal of Finance, 19(3), 425-442. http://dx.doi.org/10.1111/j.1540-6261.1964.tb02865.x

Stock, J. H., \& Watson, M. W. (2011). Introduction to Econometrics (3rd ed.). Boston: Addison-Wesley.

Vassalou, M., \& Xing, Y. (2004). Default Risk in Equity Returns. The Journal of Finance, 59(2), 831-868. http://dx.doi.org/10.1111/j.1540-6261.2004.00650.x 